\title{
Preparation and of PVA-based compositions with embedded silver, copper and zinc oxide nanoparticles and assessment of their antibacterial properties
}

Jolanta Pulit-Prociak ${ }^{1 *} \mathbb{0}$, Anita Staroń ${ }^{1}$, Paweł Staroń ${ }^{1}$, Anna Chmielowiec-Korzeniowska ${ }^{2}$, Agata Drabik², Leszek Tymczyna ${ }^{2}$ and Marcin Banach ${ }^{1}$

\begin{abstract}
A series of poly(vinyl alcohol) (PVA) based liquid compositions with addition of zinc oxide, silver and copper nanoparticles has been prepared. The compositions also contained other consistency-forming organic components. The physico-chemical properties of the products have been determined. Their $\mathrm{pH}$ and density have been assessed. Also, the size of nanoparticles has been defined with using a dynamic light scattering technique. The compositions were subjected to XRD, FT-IR and microscopic analysis as well. Thanks to the incorporation of both metal oxide and metallic nanoparticles, it was possible to enrich the products with antibacterial properties. Their inhibiting properties in the growth of microorganisms have been confirmed against both Gram-negative and Gram-positive strains such as E. coli, S. aureus and P. aeruginosa. Thanks to the ability for solidification, the compositions may be applied on a bacterially contaminated surface, and after destroying the microorganisms and its solidification, it may be peeled off along with the dead bacterial film.
\end{abstract}

Keywords: Nanosilver, Nanocopper, Zinc oxide nanoparticles, Coating, Antibacterial effect

\section{Highlights}

- Homogeneous PVA-based compositions have been prepared.

- Compositions contained among others zinc oxide, silver or copper nanoparticles.

- Thanks to the nanoparticles, the products exhibited biocidal properties.

- Biocidal effect was confirmed against E. coli, S. aureus and $P$. aeruginosa.

\footnotetext{
${ }^{*}$ Correspondence: jolanta.pulit-prociak@pk.edu.pl

${ }^{1}$ Faculty of Chemical Engineering and Technology, Institute of Chemistry and Inorganic Technology, Cracow University of Technology, Warszawska 24, 31-155 Kraków, Poland

Full list of author information is available at the end of the article
}

- It is possible to solidify compositions and detach the dead bacterial cells.

\section{Introduction}

Nanotechnology is considered to be one of the most dynamically developing sciences; it allows the improvement of existing products, devices and technological solutions but also allows the creation of new ones by using materials with at least one dimension in the range of 1-100 nm [1]. The growing state of knowledge about nanomaterials and the development of research methods makes it possible to control the size and shape of the obtained nanoparticles, which in turn, gives the materials new, favourable physico-chemical properties. The greatest progress is manifested in areas such as medicine, food

(c) The Author(s) 2020. This article is licensed under a Creative Commons Attribution 4.0 International License, which permits use, sharing, adaptation, distribution and reproduction in any medium or format, as long as you give appropriate credit to the original author(s) and the source, provide a link to the Creative Commons licence, and indicate if changes were made. The images or other third party material in this article are included in the article's Creative Commons licence, unless indicated otherwise in a credit line to the material. If material is not included in the article's Creative Commons licence and your intended use is not permitted by statutory regulation or exceeds the permitted use, you will need to obtain permission directly from the copyright holder. To view a copy of this licence, visit http://creativeco mmons.org/licenses/by/4.0/. The Creative Commons Public Domain Dedication waiver (http://creativecommons.org/publicdomain/ zero/1.0/) applies to the data made available in this article, unless otherwise stated in a credit line to the data. 
technology, electronics, chemical and material engineering, biotechnology and environmental engineering [2]. Nanomaterials are successfully used in the fight against microorganisms. The high effectiveness of nanoparticles against bacteria is of particular importance nowadays because the abuse of antibiotic therapy has resulted in the production of strains resistant to this type of therapy.

The mechanisms of bacterial destruction are varied and depend on the type of nanoparticles. Nanoparticles can penetrate the bacterial wall and form pores on the surface of the membrane, which leads to the formation of free radicals that are able to destroy the cell membrane [3]. In addition, ions formed from nanoparticles can disrupt the production of enzymes and generate reactive oxygen species (ROS), which affect DNA transcription [4].

Among nanomaterials, special attention is paid to nanometric silver. The effectiveness of its biocidal action depends on several factors: the shape, surface and size of the nanosilver particle [5]. Studies have shown that spherical and triangular forms up to $30 \mathrm{~nm}$ in size exhibit the highest fighting efficiency against microorganisms [5-11]. The antimicrobial effectiveness of silver nanoparticles is also dependent on the bacterial strain and cell wall structure [12]. Peptidoglycans located on the surface of the cell wall of Gram(+) bacteria are responsible for the proper functioning of the respiratory chain, and as a result of the action of nanosilver, they lose their properties that enable oxygen respiration, which leads to the death of the bacteria [13].

The high antimicrobial effectiveness of copper nanoparticles has also been confirmed [3, 14]. Copper nanoparticles with a diameter not exceeding $100 \mathrm{~nm}$ interacts with the surface of the cells of microorganisms, as a result of which, a bipartite copper ion is formed, which enters the cell $[15,16]$. In a microbial cell, ions produce reactive oxygen species that lead to lipid peroxidation and protein oxidation [15].

The biocidal effectiveness of nanometric metal oxides (including $\mathrm{ZnO}, \mathrm{CuO}, \mathrm{Fe}_{2} \mathrm{O}_{3}, \mathrm{Ag}_{2} \mathrm{O}, \mathrm{MgO}, \mathrm{TiO}_{2}, \mathrm{CeO}_{2}$ and $\mathrm{Al}_{2} \mathrm{O}_{3}$ ) has also been tested [17-19]. In the case of zinc oxide nanoparticles, the literature does not explicitly state the effectiveness of their action against Grampositive $(G(+))$ and Gram-negative $(G(-))$ bacteria [20, 21]. Tayel et al. [22] examined the antibacterial properties of zinc nanooxide against nine bacterial strains and observed that Gram-positive bacteria are more sensitive to its effects than Gram-negative bacteria. Reddy et al. had similar observations [23]. They showed that to inhibit the growth of Gram-negative bacterial cells, three times higher concentration of zinc oxide nanoparticles is necessary than in the case of Gram-positive bacteria. In turn, different observations were described by Pasquet and Applerot and colleagues [20,24]. According to their research, zinc oxide nanoparticles show a stronger fighting effect against bacteria built of the outer cell membrane. Therefore, the proposed mechanisms describing the operation of nanoZnO are also different. It is assumed that in the case of Gram-positive bacteria, zinc oxide adheres to peptidoglycan or the double lipid layer is characterised by high sensitivity to ROS produced as a result of $\mathrm{ZnO}$ activity [24].

The undoubted advantage of using metallic nanoparticles in the fight against microorganisms is the non-specific bacterial toxicity of these nanoparticles. According to this mechanism, nanoparticles do not bind to a specific receptor in a bacterial cell, thanks to which resistance of these bacteria does not develop [25].

The article presents research on the antibacterial activity of poly(vinyl alcohol) (PVA)-based compositions containing silver, copper and zinc oxide nanoparticles. It is intended that the composition may be applied in a liquid form on a surface that is contaminated with microbial cells. The great feature of the products is that after a few hours, it is completely solidified. Thus, after application and solidification, the composition may be detached with dead biological film. The minimal inhibiting concentration (MIC) and bacterial cell reduction against both Gram-positive and Gram-negative bacteria (Staphylococcus aureus, Escherichia coli and Pseudomonas aeruginosa) was determined.

\section{Materials and methods Materials}

The following compounds were used in this study: poly(vinyl alcohol) $(\mathrm{M}=72 \mathrm{~kg} / \mathrm{mol}, \geq 99.0 \%)$, sucrose ( $\geq 99.5 \%), \quad$ 2-hydroxyethyl cellulose $\quad(M=90 \quad \mathrm{~kg} /$ mol, p.p.a.), guar gum (p.p.a.), gelatine (p.p.a.), chitosan $(M=100-300 \mathrm{~kg} / \mathrm{mol}$, high purity), glycerol $\left(\mathrm{d}=1.26 \times 10^{3} \mathrm{~kg} / \mathrm{m}^{3}\right.$, p.p.a.), casein (p.p.a.), zinc nitrate $(\geq 99.9 \%)$, silver nitrate $(\geq 99.0 \%)$, copper chloride (99.0\%), tannic acid (ACS reagent), sodium hydroxide ( $\geq 98.0 \%)$ and acetic acid ( $\geq 99.0 \%)$. All compounds were obtained from Sigma-Aldrich. Test microorganism strains included in the study were as follows: Escherichia coli, Staphylococcus aureus and Pseudomonas aeruginosa. They were purchased from MicroBioLogics, Inc., (St. Cloud, USA). Mueller-Hinton broth, Tryptic Soy Agar (TSA) and Ringer solution were purchased from BTL Polska Sp. z o. o., Poland. All aqueous solutions were prepared using deionised water (Polwater, $0.18 \mu \mathrm{S}$ ).

\section{Methods}

Preparation of PVA-based coatings with nanoparticles

In this study, a series of PVA-based compositions with zinc oxide, silver and copper nanoparticles were prepared. The base formulation was the same for all types of 
products. The affinity of the prepared products with nanoparticles to microbiological biofilm should be enhanced. Thus, the specific compounds thanks to which the "hook effect" is achieved have been used. The organic matrix of all compositions consisted of sucrose, hydroxyethyl cellulose, guar gum, gelatine, chitosan, glycerol and casein. The adhesion of microorganisms to any surface is possible thanks to extracellular polymers which are secreted out. This group is consisted of lipopolysaccharides and proteins. Thanks to the fact that the products contain compounds such as casein (protein), sucrose (carbohydrate) or chitosan (polysaccharide), their adhesion to the surface will be increased. The adhesion of microbial cells to any surface should be considered as a multistep process. It depends on hydrodynamic forces, gravity, thermodynamic (Brownian motion) forces and van der Waals forces. The van der Waals forces make it possible to attract the cells to the material surface in an efficient way. If the distance between microbial cells and the surface is less than $1.5 \mathrm{~nm}$, then a hydrogen bonding and covalent carbon-carbon bonds are produced. The better adhesion of applied compositions is ensured by a chemical interaction of substances such as casein, sucrose, or chitosan with extracellular polymers that are secreted out by biofilm [26-28]. In the beginning, the aqueous solutions of these components were prepared. Chitosan was dissolved in acetic acid solution $(1.5 \% \mathrm{v} / \mathrm{v})$. Since casein is freely soluble in an alkaline environment, it was dissolved in $\mathrm{NaOH}$ solution at different concentrations. In order to obtain compositions with zinc oxide, its previously prepared solid phase was added directly to the dispersed composition. Zinc oxide nanoparticles were prepared according to a previously developed method [29]. Both silver and copper nanoparticles were formed in situ in the course of the compositions preparation. For this purpose, the aqueous solution of silver or copper ions source was introduced to the PVA-based mixture. Silver nitrate solution and copper chloride solution served as ion suppliers. Tannic acid aqueous solution was used as both a reducing and stabilising agent. Since the chemical reduction using tannic acid is promoted by an alkaline environment, it was provided by the addition of a casein alkaline solution. Antibacterial compositions were prepared using a mechanical stirrer and elevated temperature. First, PVA was dissolved in deionised water. After that, the rest of the reagents were added one by one with the order provided in Table 1 . The concentrations and volumes of all reagent solutions added made it possible to obtain compositions with the final concentrations of all ingredients that are presented in Table 1. The reference product did

Table 1 Concentration values of components in individual compositions, process parameters and properties of the products

\begin{tabular}{|c|c|c|c|c|c|c|c|c|c|c|c|}
\hline \multirow[t]{3}{*}{ Component } & \multicolumn{11}{|c|}{ Concentration of the component in the final product } \\
\hline & \multicolumn{3}{|c|}{ Compositions with nanoZnO } & \multicolumn{4}{|c|}{ Compositions with nanoAg } & \multicolumn{3}{|c|}{$\begin{array}{l}\text { Compositions } \\
\text { with nanoCu }\end{array}$} & \multirow[t]{2}{*}{ Ref. } \\
\hline & K1 & $\mathrm{K} 2$ & K3 & K4 & K5 & K6 & K7 & K8 & K9 & K10 & \\
\hline PVA, \% & 7.0 & & & & & & & & & & \\
\hline Sucrose, $\%$ & 0.12 & & & & & & & & & & \\
\hline Hydroxyethyl cellulose, \% & 0.10 & 0.10 & 0.01 & 0.10 & 0.10 & 0.01 & 0.01 & 0.10 & 0.10 & 0.055 & 0.10 \\
\hline Guar gum, \% & 0.01 & 0.05 & 0.01 & 0.05 & 0.05 & 0.05 & 0.05 & 0.05 & 0.05 & 0.05 & 0.05 \\
\hline Gelatine, \% & 0.05 & 0.5 & 0.5 & 0.1 & 0.5 & 0.3 & 0.5 & 0.5 & 0.5 & 0.1 & 0.3 \\
\hline Chitosan, \% & 0.01 & & & & & & & & & & \\
\hline Glycerol, \% & 14.0 & & & & & & & & & & \\
\hline Casein, \% & 0.4 & & & & & & & & & & \\
\hline $\mathrm{ZnO}, \%$ & 3.0 & 5.0 & 5.0 & - & - & - & - & - & - & - & 0 \\
\hline Silver nitrate + tannic acid $\rightarrow$ nanoAg, ppm & - & - & - & 1000 & 500 & 200 & 200 & - & - & - & 0 \\
\hline \multirow[t]{2}{*}{ Copper chloride + tannic acid $\rightarrow$ nanoCu, ppm } & - & - & - & - & - & - & - & 1000 & 200 & 200 & 0 \\
\hline & \multicolumn{11}{|c|}{ Process parameters } \\
\hline $\mathrm{C}_{\mathrm{NaOH}}, \mathrm{mol} / \mathrm{l}$ & 0.5 & 0.3 & 0.3 & 0.3 & 0.3 & 0.3 & 0.9 & 0.5 & 0.3 & 0.3 & 0.5 \\
\hline \multirow[t]{2}{*}{$\mathrm{T},{ }^{\circ} \mathrm{C}$} & 80 & 80 & 60 & 80 & 80 & 60 & 20 & 60 & 80 & 60 & 60 \\
\hline & \multicolumn{11}{|c|}{ Properties of the products } \\
\hline $\mathrm{pH}$ & 7.12 & 6.81 & 6.92 & 5.50 & 5.44 & 6.29 & 7.38 & 5.38 & 5.17 & 5.12 & 6.12 \\
\hline Density, g/ml & 1.111 & 2.997 & 1.410 & 2.903 & 2.906 & 1.125 & 1.105 & 2.925 & 2.939 & 2.915 & 2.925 \\
\hline Size, nm (DLS) & 720 & 1215 & 580 & 1464 & 407 & 1544 & 679 & 762 & 186 & 1489 & - \\
\hline Size, nm (AFM) & $300-600$ & $300-400$ & $350-600$ & 250 & 200 & 250 & 200 & 400 & 300 & 350 & - \\
\hline
\end{tabular}


not contain the nanoparticles. Table 1 also provides other process parameters. In order to ensure good dispersion of all components, the mixture was stirred for another $10 \mathrm{~min}$. Each process led to the obtaining of $40.0 \mathrm{~g}$ of antibacterial composition.

The physico-chemical properties of the liquid form of obtained compositions have been analysed. The $\mathrm{pH}$ values were checked using an Elmetron $\mathrm{pH}$ electrode. The density of compositions was assessed by the weighting method. By using a dynamic light scattering technique (DLS), it was possible to determine both the size and electrokinetic potential of the nanoparticles. The measurement was performed by Zetasizer Nano, Malvern. Before the measurement, it was necessary to prepare the samples in a specific way. Aqueous suspensions of the compositions at a concentration of $50 \mathrm{ppm}$ have been prepared. In order to suspend the compositions in the dispersing agent, the suspensions were homogenised for 1 min using an ultrasonic homogeniser (Hielscher UP50H). Compositions with silver nanoparticles were tested by a spectrophotometric method (UV 1800, Rayleigh). For this purpose, compositions have been diluted with deionised water to the concentration of silver equal to $50 \mathrm{ppm}$. In order to minimise the influence of the organic matrix, the spectra of reference sample was subtracted from spectra of the compositions. The products are intended to be used in a liquid form applied on a microbiologically contaminated surface and, after its solidification, to be peeled off along with the dead biological content. In order to perform analyses that are suitable for solid samples, the compositions have been solidified. For this purpose, $2 \mathrm{ml}$ of liquid products have been put on a Petri dish and left for their solidification. As prepared, the solid films were subjected to further analysis. The crystal structure was assessed in the course of X-Ray Diffractometry (XRD) using X'Pert PW 1752/00, Philips. In order to detect the characteristic functional groups contained in the products, the solid films were subjected to Infrared Spectroscopy with Fourier Transformation (FTIR). The samples were scanned over the range of $400-4000 \mathrm{~cm}^{-1}$ in a Nicolet 380 spectrophotometer (Thermo Fisher). The distribution of nanoparticles in the solid products was determined by both scanning electron microscopy (SEM) with energy dispersive X-ray spectrometry (EDX) and atomic force microscopy (AFM). The studies were carried out using a 1430 VP microscope (LEO Electron Microscopy) and MultiMode microscope with NanoScope IIIa and Quadrex controller (Veeco Digital Instrument).

In order to compare the effectiveness of prepared compositions, the antibacterial properties of pure nanoparticles have also been investigated. Their physico-chemical properties have also been checked. The powder of $\mathrm{ZnO}$ was assessed by XRD, FTIR and SEM techniques. Suspensions of nanoAg and nanoCu at a concentration of $1000 \mathrm{ppm}$ have been prepared based on a reduction reaction by mixing $36 \mathrm{ml}$ of metal ion source aqueous solution with $4 \mathrm{ml}$ of tannic acid aqueous solution. The concentration of silver nitrate and copper (II) chloride solutions were equal to $0.01 \mathrm{~mol} / \mathrm{l}$ and $0.0315 \mathrm{~mol} / \mathrm{l}$, respectively. The concentrations of tannic acid solutions were equal to $0.0185 \mathrm{~mol} / \mathrm{l}$ (in the case of obtaining nanoAg) and $0.0315 \mathrm{~mol} / \mathrm{l}$ (in the case of obtaining nanoCu). These amounts ensured the molar volume of reducing agent to metallic ions equal to $0.2: 1.0$. After mixing the source of metallic ions with a reducing-stabilising agent, the $\mathrm{pH}$ of the mixture was adjusted up to 8 using $\mathrm{NaOH}$ aqueous solution at a concentration of $0.1 \mathrm{~mol} / \mathrm{l}$. These suspensions were also analysed by instrumental techniques. The sizes of the nanoparticles were checked by DLS technique. The UV-Vis spectroscopy was applied to identify silver nanoparticles. The pure nanoparticles were also tested in microbiological studies. For this purpose, both silver and copper aqueous suspensions were taken at a concentration of $1000 \mathrm{ppm}$. Zinc oxide powder was suspended in water so that the final concentration of $\mathrm{ZnO}$ was equal to $5 \%$. In order to homogenise the product, the suspension was pontificated for $1 \mathrm{~min}$.

\section{Analysis of antibacterial properties of obtained compositions} In the study, the minimal inhibiting concentration (MIC) and the minimal biocidal concentration $(\mathrm{MBC})$ were determined. The evaluation of the biocidal effect of the tested materials was carried out by means of both serial two-fold dilution method and a suspension method. The studies were performed against indicator microorganisms, including Gram-positive bacteria (Staphylococcus aureus) and Gram-negative bacteria (Escherichia coli and Pseudomonas aeruginosa).

Preparation of tested materials $5 \mathrm{ml}$ of Mueller-Hinton broth $(\mathrm{MH})$ was poured into ten sterile tubes. There was $5 \mathrm{ml}$ of the tested composition introduced into the first tube (1:1 dilution). From the mixture thus obtained, $5 \mathrm{ml}$ was transferred to another tube with broth. In this way, further two-fold dilutions were obtained $(1: 2,1: 4,1: 8$, 1:16, 1:32, 1:64, 1:128, 1:256 and 1:512).

Inoculum preparation Inoculum was prepared from a 24-h bacterial culture (on TSA media). For this purpose, 3-5 cells were harvested and transferred to $5 \mathrm{ml}$ $\mathrm{MH}$ broth. The whole was incubated for $2-3 \mathrm{~h}$ at $35^{\circ} \mathrm{C}$. After this time, the inoculum density was set at $0.5 \mathrm{McF}$ by using a densimeter. This value corresponds to a density of $1-2 \times 10^{8} \mathrm{cfu} / \mathrm{ml}$. Inoculum with higher turbidity was adjusted with $\mathrm{MH}$ broth. 
Determination of $M I C$ and $(M B C)$ There was $0.1 \mathrm{ml}$ of inoculum introduced into the prepared tubes with the medium and the tested materials. The control was a tube with $\mathrm{MH}$ broth $(10 \mathrm{ml})$ without the addition of the preparation (zero test). The results were assessed after $24 \mathrm{~h}$ of incubation at $37^{\circ} \mathrm{C}$. The MIC concentration was the concentration of the tested material that completely inhibited the growth of microorganisms. The assessment consisted in measuring the turbidity of the medium after incubation. In order to determine the MIC, the bacterial culture considered negative was used to perform inoculation on TSA medium without the addition of nanoparticles. Samples were incubated for $24 \mathrm{~h}$ at $37^{\circ} \mathrm{C}$. The concentration of the material causing complete inhibition of bacterial growth was defined as MBC (macroscopic evaluation).

Determination of bacterial cell reduction Inoculates of $0.5 \mathrm{McF}$ arland density and their dilutions $\mathrm{Z}^{-1}, \mathrm{Z}^{-2}$ and $\mathrm{Z}^{-3}$ were prepared from fresh $(24 \mathrm{~h})$ cultures of microorganisms. Then, to four tubes containing $9 \mathrm{ml}$ of each of the compositions $\mathrm{K} 1, \mathrm{~K} 5, \mathrm{~K} 7$ and $\mathrm{K} 9,1 \mathrm{ml}$ of suspension from dilution Z-2 was added. The Z-3 suspension in Ringer's solution was a control sample. The study was performed according to Polish Standards PN-EN 1040 [30] and PN-EN 1275 [31]. In accordance with them, the preparation can be considered as meeting the requirements for the basic bactericidal and fungicidal activity if, under the test conditions, within $60 \mathrm{~min}$, it causes a $10^{5}$-fold reduction of viable bacteria and a $10^{4}$-fold reduction of viable fungi. Based on the standards, the contact time should be equal to $5 \mathrm{~min}$ and $1 \mathrm{~h}$. After that time, $0.1 \mathrm{ml}$ of suspension from each tube was inoculated onto agar plates (TSA for S. aureus, McConkey for E. coli and enriched agar for $P$. aeruginosa). The plates were incubated for $24 \mathrm{~h}$ at $37^{\circ} \mathrm{C}$. After this time, the grown colonies were counted. On their basis, the logarithmic reduction ratio was calculated.

\section{Results and discussion}

\section{PVA-based coatings with nanoparticles}

Ten PVA-based compositions have been obtained. The products differed in colour. Compositions with zinc oxide nanoparticles were white. The presence of both silver and copper nanoparticles led to the formation of reddish or brownish products.

The $\mathrm{pH}$ values of prepared compositions are provided in Table 1. The pH was in the ranges of 5.12-5.38 (compositions with nanoCu); 5.44-7.38 (compositions with nanoAg) and 6.81-7.12 (compositions with nanoZnO). It was obvious that a higher concentration of sodium hydroxide solution, which was used to dissolve casein, caused a higher $\mathrm{pH}$ of the product. Table 1 presents the results of the density of the measured compositions. One may conclude that the density is affected by both hydroxyethyl cellulose and guar gum content. Gelatine does not seem to influence this parameter. These observations are in-line with other researchers' studies. Both hydroxyethyl cellulose and guar gum are able to rapidly increase the density of consumer products. They are applied in order to moderate the density and viscosity of materials [32-35]. The measured size values of zinc oxide, silver and copper nanoparticles are provided in Table 1 . The interpretation of these results must be critical. Since the DLS technique is based on the Mie theory, one should be aware that it is assumed that particles are spherical. It may be especially applied in the interpretation of zinc oxide particles. Flower-like particles may be approximated to spherical shape, and thus, their size seems to be bigger. The influence of the organic matrix poses another problem. Even though the refractive index, which is characteristic for analysed particles, has been set during the measurements, there were still macromolecules that could affect the values provided by the apparatus [36]. This may be related to the multiple scattering effect, which can lead to misleading results. Thus, microscopic techniques are better for assessing the size of nanoparticles in such products. Figure 1a presents the results of spectrophotometric analysis. Thanks to the surface plasmon resonance, silver nanoparticles have a UV-Vis absorption maximum within the range of 400 and $500 \mathrm{~nm}[17,37]$. The spectra of compositions with silver nanoparticles after subtracting the background originating from the reference sample exhibit characteristic peaks. Unfortunately, despite efforts to avoid the influence of organic matter, due to the organic compounds which are were still present, an increase in background is observed that is caused by the absorption of all other unmarked components of the sample. However, this fact does not interfere with the successful identification of nanosilver in the tested compositions. Diffractograms of solid phase of obtained compositions are presented in Fig. 1b. It is clearly seen that zinc oxide nanoparticles contained in K1-K3 compositions may be identified. This was confirmed by reflections at $31.6^{\circ}$, $34.4^{\circ}, 36.1^{\circ}, 47.6^{\circ}$ and $56.6^{\circ}$ of $2 \theta$ angle $[38,39]$. This pattern is in line with the lattice planes (100), (002), (101), (102) and (110) respectively [40]. The plots of compositions with copper and silver nanoparticles did not differ from the plot of the reference sample. This technique was not adequate to reveal silver and copper nanoparticles presence in the products. This is due to the fact that the concentration of both silver and copper nanoparticles in the tested products was too low. The concentration of nanoparticles included in K4-K10 samples was from 50 to 250 times lower than in compositions with zinc oxide nanoparticles. The reflections originating from organic matter covered the peaks obtained for silver and copper 

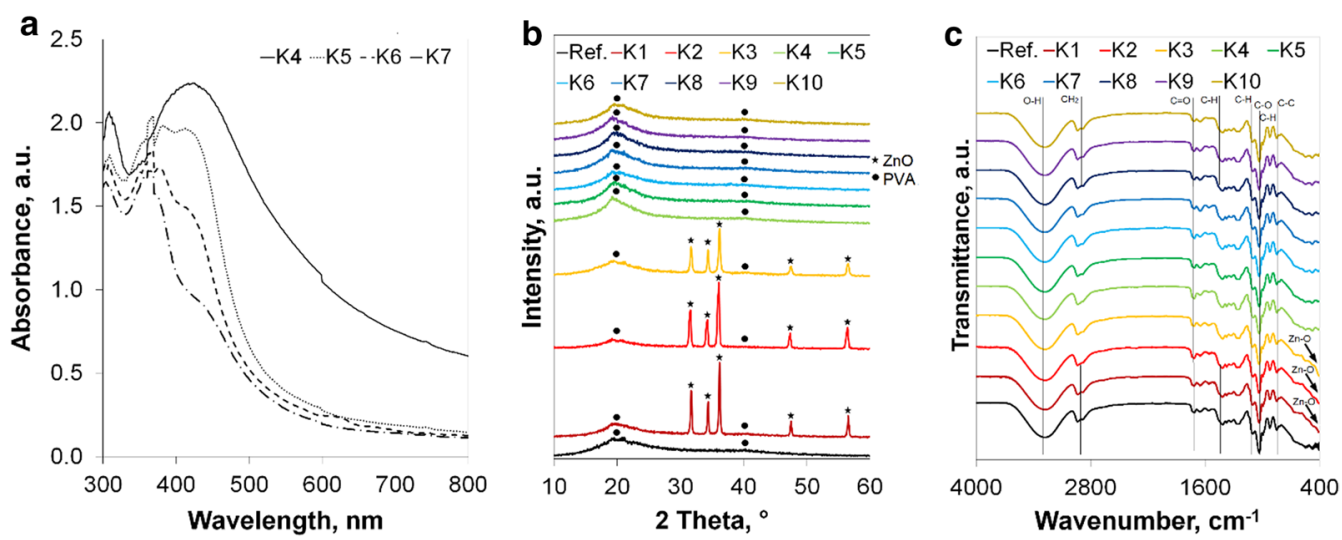

Fig. 1 a UV-Vis spectra of liquid compositions; $\mathbf{b}$ XRD diffractogram of all compositions in solid phase and $\mathbf{c}$ FTIR spectra of all compositions in the solid phase

nanoparticles. The lack of other clear reflections in the $\mathrm{X}$-Ray results makes it seem that the compositions were loaded with amorphous or semi-crystalline substances. The semi-crystalline structure of PVA was confirmed by reflections at $19.5^{\circ}$ of $2 \theta$ angle [41]. The incorporation of neither silver nor copper nor zinc oxide nanoparticles did not worsen the intensity of these major peaks, which was the desired effect. The amorphous phase of PVA may be identified by the reflections at around $40^{\circ}$. The intensity of the major amorphous reflection may be enhanced by the presence of the rest of organic matter. The applied substances also exhibit a Bragg's reflection at around $20^{\circ}$ of $2 \theta$ angle [42-47]. In order to assess the bonds in the prepared compositions, FTIR spectra of the solid form of the obtained products have been recorded in the range $400-4000 \mathrm{~cm}^{-1}$. FTIR spectra of all solid compositions are presented in Fig. 1c. The identification of $\mathrm{ZnO}$ in $\mathrm{K1}$ K3 compositions may be done based on peaks observed at $410 \mathrm{~cm}^{-1}$. These peaks correspond to $\mathrm{Zn}-\mathrm{O}$ symmetric bending vibrations. The major peaks at $3300 \mathrm{~cm}^{-1}$ come from $\mathrm{O}-\mathrm{H}$ stretching vibrations. This groups originate from water molecules, which are adsorbed on the compositions' surfaces $[48,49]$. The peaks observed at $2930 \mathrm{~cm}^{-1}$ may be due to $\mathrm{CH}_{2}$ stretching vibrations [50]. Peaks at 1710 and $1415 \mathrm{~cm}^{-1}$ may be assigned to $\mathrm{C}=\mathrm{O}$ carbonyl stretching vibrations and $\mathrm{C}-\mathrm{H}$ bending vibrations [51] of the $\mathrm{CH}_{2}$ group, respectively. The presence of $\mathrm{C}-\mathrm{H}$ deformation vibrations, $\mathrm{C}-\mathrm{O}$ stretching and $\mathrm{C}-\mathrm{C}$ stretching vibrations is confirmed by peaks at 1324, 1097 and $840 \mathrm{~cm}^{-1}$ [49], respectively. Peaks at $1030 \mathrm{~cm}^{-1}$ may originate from $\mathrm{C}-\mathrm{H}$ deformation vibrations of the aromatic groups [52]. These peaks confirm the presence of organic matter in the obtained products. The appearance of spectra of compositions with nanoparticles does not differ from the reference product, which means that the organic matrixes were not changed due to the incorporation of inorganic nanoparticles.

Figure 2 presents the exemplary results of microscopic analysis. AFM microphotographs show the shape and size of nanoparticles. All of them were spherical and well dispersed in the organic matrix. The size of the nanoparticles differed from the results of DLS analysis. Based on the AFM microphotographs, one may observe that the size of $\mathrm{ZnO}$ nanoparticles in the $\mathrm{K} 1$ composition was in the range of $300-600 \mathrm{~nm}$. Silver nanoparticles in the $\mathrm{K} 5$ composition did not exceed $200 \mathrm{~nm}$, and the size of copper nanoparticles in the $\mathrm{K} 9$ composition was equal to $300 \mathrm{~nm}$. The size of nanoparticles contained in the rest of compositions are provided in Table 1.

Figure 3 presents the results of analysis of physicochemical properties of pure nanoparticles. XRD diffractograms of $\mathrm{ZnO}$ nanoparticles are shown in Fig. 3a. The characteristic reflections are clearly visible. The peaks at $31.6^{\circ}, 34.4^{\circ}, 36.1^{\circ}, 47.6^{\circ}$ and $56.6^{\circ}$ of $2 \theta$ angle confirm the presence of zinc oxide $[38,39]$. The diffractogram matches with the lattice planes (100), (002), (101), (102) and (110) respectively [37]. FTIR spectra of pure zinc oxide is presented in Fig. 3b. One may expect the band in the region below $1000 \mathrm{~cm}^{-1}$, which proves the bonds between metal and oxygen [53]. The band occurring between 400 and $580 \mathrm{~cm}^{1}$ confirms the stretching vibration of $\mathrm{Zn}-\mathrm{O}$. The peak at around $1400 \mathrm{~cm}^{-1}$ may be assigned to the $\mathrm{H}-\mathrm{O}-\mathrm{H}$ bending vibration, which occurs due to the adsorbed moisture on the zinc oxide surface. The presence of water may be also confirmed by a wide band between 3000 and $3650 \mathrm{~cm}^{-1}$. The size of zinc oxide nanoparticles may be assessed based on SEM microphotography (Fig. 3c). One may conclude that the smallest dimensions of particles range from 80 to $300 \mathrm{~nm}$. Their shape is spherical or the particles are like elongated balls. 
a

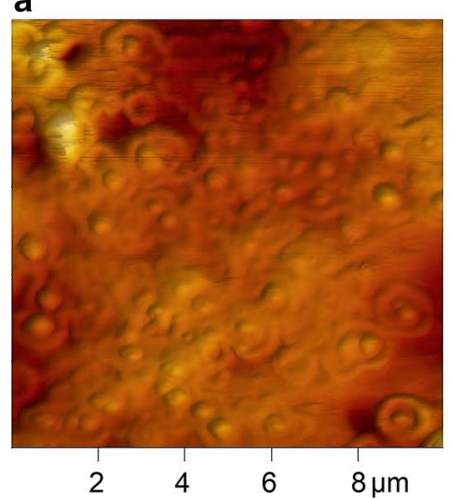

b

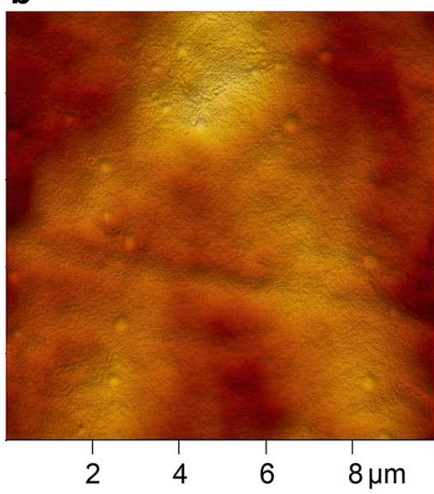

C

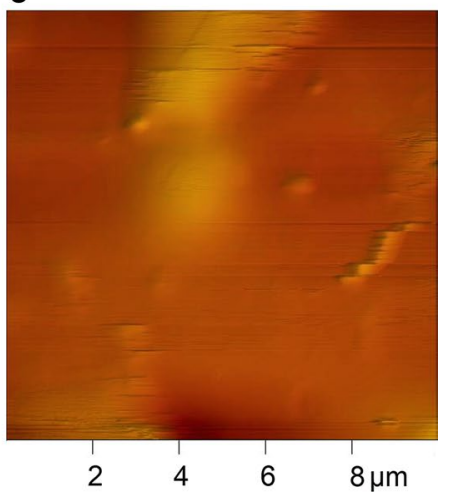

Fig. 2 AFM microphotographs of compositions a K1; b K5 and $\mathbf{c}$ K9

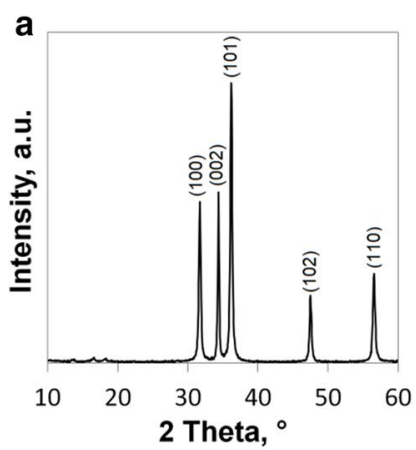

d

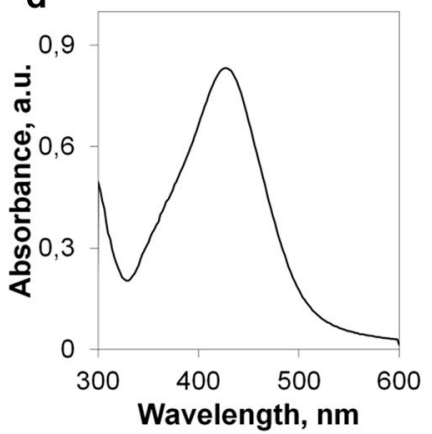

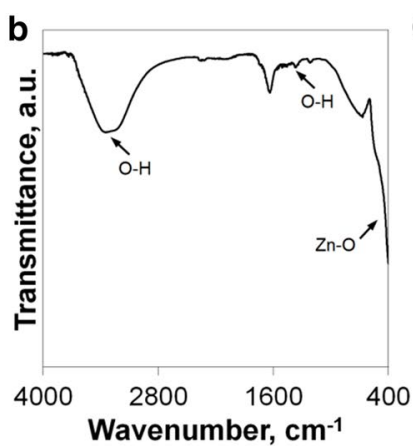

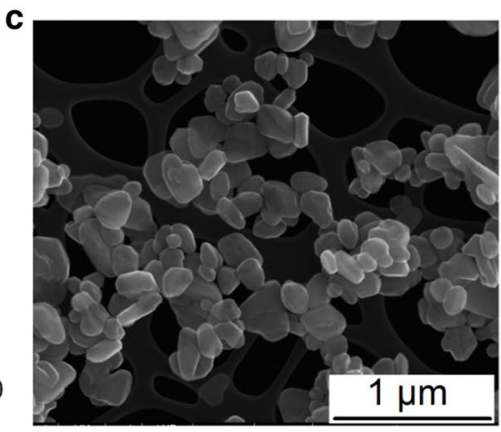

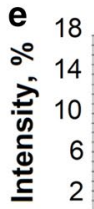

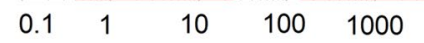

f Size, $\mathrm{nm}$

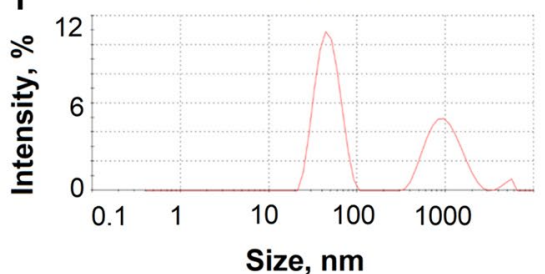

Fig. 3 Results of analysis of physico-chemical properties of pure nanoparticles $\mathbf{a} X \mathrm{RD}$ of nanoZnO; $\mathbf{b}$ FTIR of nanoZnO; c SEM microphotographs of nanoZnO; $\mathbf{d}$ UV-Vis spectra of nanoAg; $\mathbf{e}$ DLS histogram of nanoAg and $\mathbf{f}$ DLS histogram of nanoCu

The edges of particles are clearly seen, which means that they are well dispersed. Figure $3 \mathrm{~d}$ shows the UV-Vis spectra of aqueous suspension of silver nanoparticles diluted to $50 \mathrm{ppm}$. As expected, the major peak occurs between 400 and $500 \mathrm{~nm}$, and its maximum absorbance is at $\lambda=434 \mathrm{~nm}$. That confirms the obtaining of pure silver nanoparticles $[17,37]$. The results of both nanoAg and nanoCu size measurements are provided in Fig. 3e, $\mathrm{f}$. There is only one dominant size of silver nanoparticles that is manifested by a thin peak whose maximum occurs at $62 \mathrm{~nm}$. In the case of copper nanoparticles, one may observe three peaks. The first major peak is at $48 \mathrm{~nm}(60.2 \%)$. There are also some bigger agglomerates of nanoparticles, and their presence is confirmed by the 
second peak at $1010 \mathrm{~nm}$ (38.1\%). Only $1.7 \%$ of nanoparticles form agglomerates with a size of $5012 \mathrm{~nm}$.

\section{Antibacterial properties of obtained coatings}

The analysis of anti-microbial properties was conducted against three bacteria strains. Two of them were Gram-negative bacteria ( $E$. coli and $P$. aeruginosa), and the $S$. aureus strain was a Gram-positive bacteria. Figure 4 presents the MIC results determined for all tested products (compositions, aqueous suspensions of pure nanomaterials and the reference sample). For easier interpretation of the results, the minimum inhibitory concentration for zinc oxide is expressed in ppm unit. Such a notation allows the data to be compared. The reference product did not exhibit any inhibiting properties in the growth of the tested bacteria. It was a great medium for development of the strains. In fact, the reference sample consisted of organic matter, and it was a reach source of carbon for the microorganisms [54-56]. Despite the fact that the matrix of the compositions with nanoparticles was the same as in the reference product,
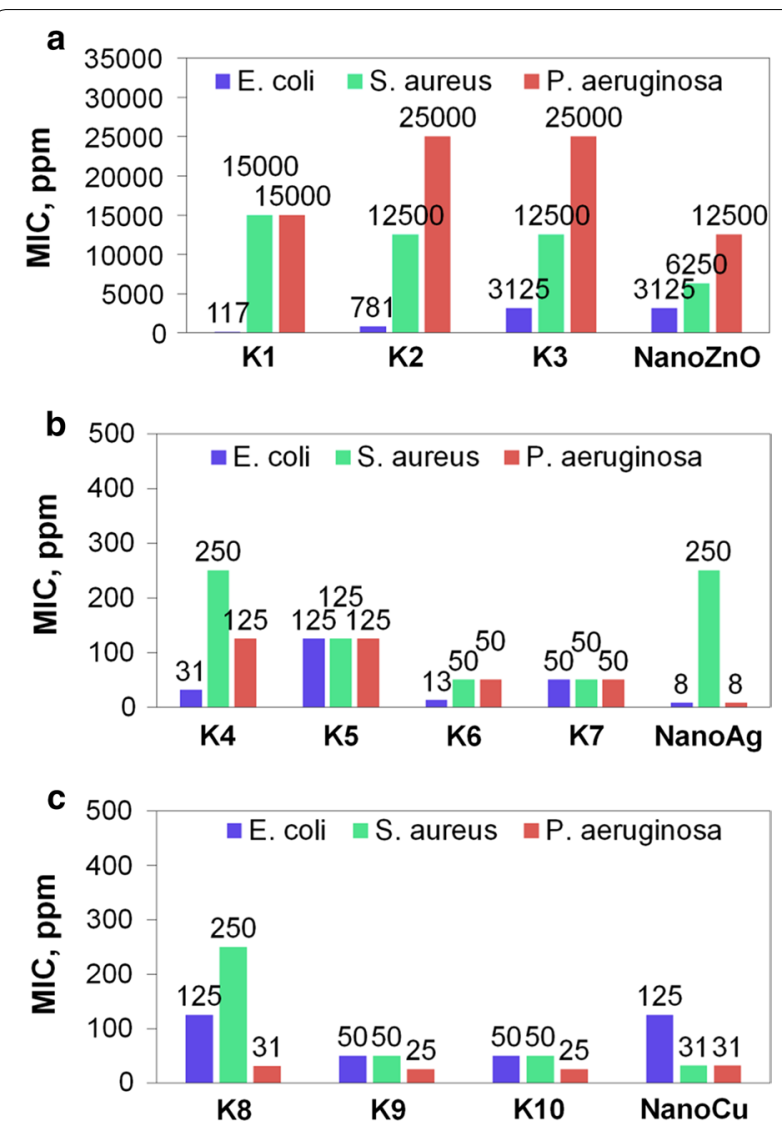

Fig. 4 a-c Results of MIC analysis against bacteria strains a compositions with nanoZnO; $\mathbf{b}$ compositions with nanoAg and $\mathbf{c}$ compositions with nanoCu) their antimicrobial properties may be observed. Analysis of the influence on the E. coli strain may conclude that the best inhibiting properties were provided by silver nanoparticles in both forms (compositions and as a pure agent). The action of copper nanoparticles in both forms was a little bit worse; however, it remained at a similar level. Zinc oxide nanoparticles in pure form and incorporated into the compositions structure exhibited the worst biocidal properties against the E. coli strain. This comparison is based on the MIC values expressed in the unified unit. Zinc oxide nanoparticles, in general, exhibited the weakest antibacterial activity. This was also confirmed in the case of both $S$. aureus and $P$. aeruginosa. Copper nanoparticles in both forms exhibited the strongest inhibiting properties against those bacteria. Silver had a moderated influence on the development of $S$. aureus and P. aeruginosa. Comparison of different forms of nanoparticles showed other dependencies. Not all pure aqueous suspensions of the tested nanoparticles exhibited better activity than nanoparticles included in the structure of the tested compositions. One might have expected that pure nanoparticles have stronger inhibiting properties in the development of bacterial strains. However, these studies confirmed that even though the active agent was incorporated in the organic matrix, it also had the ability to destroy the microorganisms. In the case of E. coli $(\mathrm{G}(-))$, only pure nanoAg exhibited better inhibiting properties. In order to inhibit the growth of this strain, the compositions with nanoAg at a concentration of $8 \mathrm{ppm}$ had to have been applied. In general, both compositions with nanoZnO and nanoCu had a better antibacterial activity than the pure nanoparticles. The opposite phenomena may be observed in the case of the Gram-positive bacteria, S. aureus. Neither $\mathrm{ZnO}$ nor $\mathrm{Cu}$ nanoparticles contained in the compositions exhibited as strong an inhibiting action as in the case of the pure nanoparticles. Only compositions with nanoAg (K5, K6 and K7) were more effective agents compared to the pure nanoAg. These results may be related to the structure of the cell wall of Gram-positive bacteria. The murein molecules, which consist of long polysaccharide chains cross-linked by peptide bridges that are located in such bacteria, may be a more effective barrier against attacking agents. $\mathrm{ZnO}$ and $\mathrm{Cu}$ nanoparticles eluted from compositions are probably still covered by a huge molecules of stabilising organic components, and thus, they are not able to interrupt the wall in the same manner as pure nanoparticles. Only silver, which is a quite strong antibacterial agent, manages with that despite being surrounded by other molecules. However, one may observe that the action of silver against Gram-negative bacteria, $\mathrm{G}(-)$, is still better than in the case of Gram-positive bacteria, $G(+)$. That also confirms the huge influence of the 
structure of the cell wall on the activity of the biocidal agent. The Gram-negative bacterial cell wall differs from Gram-positive bacterial cell wall structure. The thickness of Gram-negative bacteria cell wall is about $30 \mathrm{~nm}$ while the thickness of Gram-positive bacteria is around 3-4 $\mathrm{nm}$ [57]. The cell wall of $\mathrm{G}(-)$ bacteria consists of a cytoplasmic membrane, a thin peptidoglycan layer and the external membrane that contains lipopolysaccharide. Contrary to $\mathrm{G}(+)$ bacteria, the cytoplasmic membrane is further away from the outer membrane. Also, the network of peptidoglycan chains is more loosely packed. This is the reason for more free penetration of the irritant into the cell [58].

The action of pure $\mathrm{ZnO}$ and $\mathrm{Cu}$ nanoparticles was better in the case of $P$. aeruginosa $(\mathrm{G}(-))$ bacteria. These results confirm that as opposed to the predictions, not only pure nanoparticles exhibit more effective inhibiting properties in the development of different bacteria strains. The particles incorporated in the structure of PVA-based compositions also have the ability to move and be released from the product and act as effective antibacterial agent. Seong et al. [59] suggested that the mechanism of antibacterial action of nanoparticles may be explained by their direct contact with cells. Nanoparticles may plug the spaces in the microorganism membrane. That causes physical changes in in the membrane which leads to its damage. As a consequence, a leakage of cell content occurs and the bacteria cell is not able to stay alive anymore. What is more, the electric charge of cell membrane is another issue of matter. Negative electric charge which origins from the presence of carboxylic, phosphate and amin groups attracts the positive charged nanoparticles [60].

Another issue which should be discussed is the size of nanoparticles. In the case of $\operatorname{Gram}(-)$ bacteria this factor is extremely important when assessing the antibacterial activity. It was demonstrated that the strongest antibacterial effect on Gram(-) bacteria was performed by silver, copper and zinc oxide nanoparticles, respectively. However, here the size of nanoparticles should be considered. In fact, the strongest antibacterial effect was achieved in case of using compositions containing the smallest nanoparticles and the activity was weaker when the particles were greater. This phenomenon may be explained by the structure of Gram(-) membrane which is much more packed. This fact results in that the smallest nanoparticles are most likely to penetrate the cell membrane.

In analysing the process parameters in obtaining the tested compositions, one may note that in the case of compositions with silver nanoparticles, the best results were achieved when the concentration of hydroxyethyl cellulose was the lowest. This resulted in lower density of the product. That means that the particles were more moveable when the density was lower. The density was also the deciding factor when using compositions with zinc oxide nanoparticles. What is more, the temperature of processing was another important factor. The higher temperature led to the obtaining of more active compositions. This may be related with the higher degree of nanoparticles dispersion, which is achieved at a higher temperature of the process. This observation concerned all types of compositions. In the case of compositions with copper nanoparticles, it may be assumed that the size of particles influenced the inhibiting activity. The smaller the nanoparticles were, the more effective action was achieved.

Figure 5 presents the results of logarithmic reductions of tested strains after 5 and $60 \mathrm{~min}$ of contact with several chosen compositions. It may be seen that in the case of compositions with nano $\mathrm{ZnO}$, the logarithmic reduction of all strains was higher after a longer time of contact. The biocidal effect against Gram-negative bacteria was also greater after a longer time when using compositions with nanoAg and nanoCu. In some cases, (K5 vs $P$. aeruginosa and $\mathrm{K} 9$ vs $E$. coli), the inhibiting action was weaker after a longer time of contact. This may be due to the fact that after $1 \mathrm{~h}$ of exposure, bacteria started to consume the tested materials. These compositions had the highest content of hydroxyethyl cellulose, guar gum and gelatine which may have served as an energy source.

Silver nanoparticles have been confirmed to exhibit satisfying anti-microbial properties in studies of other researchers. Panpaliya et al. [61] conducted an analysis of biocidal activity of nanosilver against strains such as Streptococcus mutans, Streptococcus oralis, Candida albicans, Lactobacillus acidophilus and Lactobacillus fermentum, which are common dental pathogens. In their studies, they used both nanoAg nanoparticles at size of $30-50 \mathrm{~nm}$ and Chlorhexidine Gluconate $\% \mathrm{v} / \mathrm{w}$, which is used as commercial biocidal product. It has been found that nanoAg suspension is a five times more effective

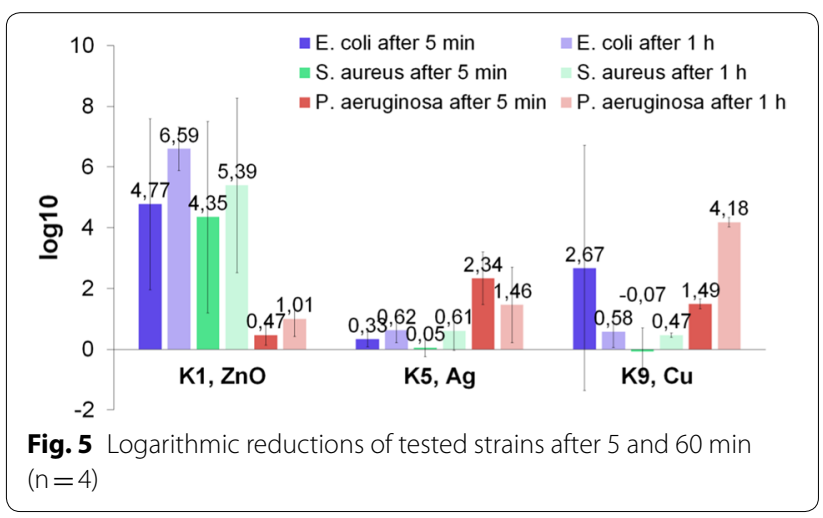


destroying agent than the commercial formulation. The lowest values of MIC for silver nanoparticles were equal to $2.81 \mathrm{mg} / \mathrm{dm}^{3}$ (against Candida albicans) and $15 \mathrm{mg} /$ $\mathrm{dm}^{3}$ (against Lactobacillus acidophilus). The medium value of $45 \mathrm{mg} / \mathrm{kg}$ was achieved against Streptococcus oralis. Higher MIC values were obtained against Streptococcus mutans $\left(60 \mathrm{mg} / \mathrm{dm}^{3}\right)$ and Lactobacillus fermentum $\left(90 \mathrm{mg} / \mathrm{dm}^{3}\right)$. Concerning the fact that the PVA-based compositions contained also organic matrix, the obtained values of MIC are very satisfying.

Similar studies were performed by Petrus et al. [62] The researchers applied commercially available aqueous suspension of colloidal silver at a concentration of $100 \mathrm{mg} / \mathrm{dm}^{3}$ with particles sized from 1 to $100 \mathrm{~nm}$. The activity of nanosilver was tested against the Escherichia coli, Listeria monocytogenes, Salmonella enterica serovar Typhi, Vibrio cholerae, Vibrio parahaemolyticus, Bacillus cereus and Staphylococcus aureus strains. These microorganisms are known to be common foodborne pathogens. It turned out that nanosilver is an effective agent against both $\mathrm{G}(+)$ and $\mathrm{G}(-)$ bacteria. The values of MIC varied depending on the specific strain. The lowest inhibiting concentration was equal to $7.71 \mathrm{mg} / \mathrm{dm}^{3}$ (against Vibrio cholerae witch is $\mathrm{G}(-)$ bacteria). The highest MIC was achieved against Listeria monocytogenes $\left(24.58 \mathrm{mg} / \mathrm{dm}^{3}\right)$, which is also a $G(-)$ bacteria. Despite the fact that from statistical point of view there is no difference between the activity against different type of bacteria $(G(+)$ and $\mathrm{G}(-)$ ), a slightly more effective activity may be observed against Gram-negative bacteria. This is in-line with the results of experiments provided in this paper. Kędziora et al. [63] presented very interesting studies on defining anti-microbial properties of nanocomposites consisting of partially reduced graphene with incorporated nanosilver with nanoparticles of 5-20 nm. The bacterial standard strains, such as Staphylococcus aureus, Escherichia coli and Klebsiella pneumoniae (as well as their clinical isolates), were treated with aqueous suspension of the nanocomposite at varied concentrations $(0.25-512 \mathrm{mg} /$ $\mathrm{dm}^{3}$ ). These bacterial strains were chosen due to the fact that they very often colonise wounds, including iatrogenic and hospital infections. Similar to the results presented in this paper, the authors concluded that Gram-negative bacteria are more sensitive to the activity of nanosilver compared to Gram-positive bacteria. The bacteriostatic concentration values against all bacteria were in the range $0.4-1.6 \mathrm{mg} / \mathrm{dm}^{3}$, while biocidal concentrations were between $0.4-3.2 \mathrm{mg} / \mathrm{dm}^{3}$.

Karimipour and Tanomand [64] conducted research on the antibacterial effect of nanosilver particles against Gram-negative bacteria, i.e. Pseudomonas Aeruginosa. They applied suspension of nanoAg prepared by dispersing nanoparticulate powder in nutrient broth. The authors used two different types of nanoparticles. One of them consisted of nanoparticles of $20 \mathrm{~nm}$ and the other one of $5 \mathrm{~nm}$ nanoparticles. The concentration of nanoAg in the suspension varied by series dilution method, and it was equal to 312 to $40,000 \mathrm{mg} / \mathrm{kg}$. The researchers performed tests by both well diffusion and disc diffusion method. In both techniques, the results were similar. One conclusion regards the influence of the nanoAg concentration and the other one concerns the influence of nanoparticles size. The higher the concentration of nanoAg, the stronger an anti-microbial effect may be achieved. The MIC values were equal to $75 \mathrm{mg} / \mathrm{kg}$ for $5-\mathrm{nm}$ particles and $625 \mathrm{mg} / \mathrm{kg}$ for $20-\mathrm{nm}$ particles. The MBC values were $156 \mathrm{mg} / \mathrm{kg}$ for $5-\mathrm{nm}$ particles and $1250 \mathrm{mg} / \mathrm{kg}$ for 20-nm particles. Thus, the reduction of nanoparticle sizes leads to the achievement of more effective bacteriostatic and biocidal properties.

In the studies conducted by Krishnan et al. [65], it was confirmed that suspension of nanosilver dispersed in Brain Heart Infusion (BHI) broth at a concentration of $5 \mathrm{mg} / \mathrm{ml}$ is a biocidal factor in destroying $99.9 \%$ of Enterococcus faecalis strain. The size of nanoparticles was of 45-50 nm. Considering the fact that Enterococcus faecalis are highly resistant for the common agents, it may be concluded that nanosilver is able to manage with their pathogenic activity in a rewarding manner.

Very interesting studies were conducted by Rautela et al. [66]. Beside performing typical anti-microbial properties assessment, the researchers also tried to explain the possible mechanism of action of nanoAg against Grampositive (Bacillus cereus and Staphylococcus aureus) and Gram-negative bacteria (Escherichia coli). It was evidenced that relatively low concentrations of greensynthesised silver nanoparticles were enough to achieve satisfying bacteriostatic effect. For Bacillus cereus, the concentration was equal to $5.2 \mathrm{mg} / \mathrm{dm}^{3}$, for Staphylococcus aureus, $2.6 \mathrm{mg} / \mathrm{dm}^{3}$ and for Escherichia coli, $2.0 \mathrm{mg} /$ $\mathrm{dm}^{3}$. In order to assay the influence of nanoparticles on the content of extracellular matter after different times of contact, authors determined that the concentration of reducing sugars and proteins in supernatant obtained after centrifugation of suspension consists of nanoAg and bacteria inoculum. In each case, the content of both types of molecules was higher with time. It was concluded that silver nanoparticles may enhance the permeability of the cell membrane, which leads to the leakage of molecules necessary for life.

Also, anti-microbial properties of zinc oxide nanoparticles have been the object of the studies of other scientists. Yousef and Danial [67] conducted analysis on the activity of nanoZnO against food borne pathogens such as Bacillus subtilus, Bacillus megaterium, Staphylococcus aureus, Sarcina lutea, Escherichia coli, Pseudomonas aeruginosa, 
Klebsiella pneumoniae, Proteus vulgaris, Candida albicans and Aspergillus niger. While maintaining the concentration of nanoZnO in a dispersing agent at a constant level $\left(20 \mathrm{mg} / \mathrm{dm}^{3}\right)$, after preparation of agar cultures, the inhibiting zone was assessed. It has turned out that the greatest, not-grown areas were obtained in the case of Bacillus subtilus, Escherichia coli and Staphylococcus aureus. The worst inhibiting activity was achieved against Aspergillus niger and Proteus vulgaris. The authors also managed to determine the MIC and MBC values. The obtained results showed that the development of all studied strains was completely inhibited in the tested concentration range $\left(0.5-20 \mathrm{mg} / \mathrm{dm}^{3}\right)$. It has been concluded that zinc oxide nanoparticles may be an effective bacteriostatic against the development of the studied strains. On the other hand, their biocidal properties are not satisfying. However, authors claim that the price of zinc oxide is an encouraging factor in applying it in anti-microbial products. Iranian researchers [68] have documented the anti-microbial activity of zinc oxide nanoparticles against ten human pathogens, including Escherichia coli, Klebsiella pneumoniae, Pseudomonas aeruginosa, Serratia marcescens, Salmonella typhi, Acinetobacter baumannii, Citrobacter freundii, Proteus mirabilis, Staphylococcus aureus and Bacillus cereus. The bioassay was based on the agar well diffusion method. Both MIC and MBC values were also determined. For comparison, scientists used popular antibiotics (gentamicin, ampicillin, nalidixic acid, amoxicillin, amikacin, ciprofloxacin, co-trimoxazole, norfloxacin and cephalexin). The authors also observed concentration-dependence in destroying the strains. The inhibiting zone was greater when the content of nanoZnO was higher (from 2.5 to $160 \mathrm{mg} / \mathrm{ml}$ ). Compared to the control group, which consisted of antibiotics, a significant bacteriostatic effect was noted. The group of strains that were most susceptible for inhibiting activity of zinc oxide nanoparticles included $S$. aureus, $S$. marcescens and E. coli. However, it was required to apply a higher concentration of nanoZnO to completely destroy these microorganisms $(20 \mathrm{mg} / \mathrm{ml})$. A lower concentration $(10 \mathrm{mg} / \mathrm{ml})$ was enough to kill $P$. aeruginosa, A. baumannii, K. pneumoniae and S. aureus.

The destroying action of $\mathrm{ZnO}$ nanoparticles against Pseudomonas aeruginosa has also been proved in the studies of Aysa and Salman [69]. Particles ranging from 23 to $29 \mathrm{~nm}$ served in the microbiological assessment. Some powder of nanoZnO were modified by addition of oleic acid. This operation ensured a better biocompatibility. It was figured out that a suspension at a concentration of $20 \mathrm{mg} / \mathrm{dm}^{3}$ was an effective inhibiting agent.

Also, Almoudi et al. [70] reviewed the studies on zinc oxide activity against Streptococcus mutans, which is common oral pathogen. Based on their research, it may be concluded that nanoZnO may play a role as an effective antibacterial agent, even at very low concentrations. The minimal inhibitory concentration is equal even to $0.39 \mathrm{mg} / \mathrm{ml}$, and the minimal biocidal effect is achieved when applying nano $\mathrm{ZnO}$ at $3.125 \mathrm{mg} / \mathrm{ml}$. Authors concluded that zinc oxide nanoparticles may play a role as active agents in both oral and dental preparations.

A very interesting application of silver combined with $\mathrm{FeO}_{2}$ and $\mathrm{FO}_{2}$ nanoparticles was presented in the work of Abdelhamid et al. [71]. Authors used such constructs for destroying different pathogenic microorganisms. Polyethylene glycol played a dual role. First at all it served as a stabilizing agent for nanoparticles. It also enhanced the biocompatibility to the live matter. It was found out that such products may be used as an efficient material acting as antibacterial agent. What is more, thanks to the fact that the nanoparticles have magnetic properties, they may be easily removed from the treated environment using a small magnetic bar. This feature makes the product highly usable.

Wu et al. [72] presented a novel method to destroy both Gram-negative and Gram-positive bacteria with using stannous dioxide $\left(\mathrm{SnO}_{2}\right)$ modified with graphene (G) nanoparticles. The authors reported the activity against Pseudomonas aeruginosa and Staphylococcus aureus as model strains. Pure graphene nanoparticles were also tested. It was figured out that due to the synergic effect, merging $\mathrm{SnO}_{2}$ with graphene gives much better results in destroying both types of bacteria. Authors suggest that this result is achieved thanks to the fact that the applied nanoparticles block the gaps by which the nutrients are taken and that leads to the cell death.

Abdelhamid and $\mathrm{Wu}$ [73] conducted studies on using multifunctional graphene magnetic nanosheet decorated with chitosan as a biosensor for sensitive detection of pathogenic bacteria such as Pseudomonas aeruginosa and Staphylococcus aureus. This phenomena is possible thanks to the non-covalent interactions between the obtained construct pathogenic and bacteria. The detection of bacteria signals is achieved by a direct fluorescence measurements. Due to the fact that the product has increased ratio of surface area to its volume, its sensitivity is enhanced. Its relatively low price is also a great advantage.

\section{Conclusions}

A series of PVA-based compositions with antibacterial nanoparticles has been prepared. The inhibiting properties of compositions with nanoZnO, nanoAg and nanoCu in development of both Gram-positive and Gram-negative bacteria have been confirmed. Antimicrobial activity was tested against $E$. coli, P. aeruginosa and S. aureus strains. Compositions with silver nanoparticles exhibited the best 
antibacterial effect against $E$. coli strain. Zinc oxide nanoparticles acted as the worst antibacterial agent in the case of Gram-negative bacteria. Copper nanoparticles gave the strongest inhibiting properties against $S$. aureus and $P$. aeruginosa strains. The structure of cell wall is a very important factor in assessment the antimicrobial properties. It influences on the migration of used agents. The size of applied nanoparticles is another crucial factor. In general, smaller nanoparticles give better antimicrobial effect. Thanks to the fact that it is possible to solidify the products, they may find applications in places in which the biocidal effect is particularly desired. The composition may be applied on a microbiologically contaminated surface, and after its solidification, it may be detached along with dead biocidal film. The content of some organic compounds, such as chitosan or casein, may be helpful in attracting the microbial film by forming the bonds between these molecules and the polymers that are excreted by the cells.

\section{Acknowledgments}

We thank National Science Centre, Poland for the grants and financial support to this research.

\section{Authors' contributions}

JPP: concept, design and writing of the manuscript, AS: analysis of physicochemical properties of obtained products, writing of the manuscript, PS: performing of the experiments, obtaining of the compositions, ACK: selection of the methodology for microbiological tests depending on the physicochemical form of the tested materials, writing of the manuscript, AD: performing of the microbiological studies, writing of the manuscript, LT: concept on microbiological studies, MB: interpretation of the obtained results. All authors read and approved the final manuscript.

\section{Funding}

This research was supported by National Science Centre, Poland (Grant No. UMO-2016/23/D/ST8/00016)

\section{Availability of data and materials}

All data generated or analysed during this study is available from corresponding author on reasonable request.

\section{Ethics approval and consent to participate}

Not applicable.

\section{Consent for publication}

All authors consent for the manuscript to be published.

\section{Competing interests}

The authors declare that they have no competing interests.

\section{Author details}

${ }^{1}$ Faculty of Chemical Engineering and Technology, Institute of Chemistry and Inorganic Technology, Cracow University of Technology, Warszawska 24, 31-155 Kraków, Poland. ${ }^{2}$ Department of Animal Hygiene and Environmental Hazards, University of Life Sciences, Akademicka 13, 20-950 Lublin, Poland.

Received: 21 April 2020 Accepted: 6 October 2020

Published online: 21 October 2020

\section{References}

1. Teulon J-M, Godon C, Chantalat L, Moriscot C, Cambedouzou J, Odorico $M$, et al. On the operational aspects of measuring nanoparticle sizes. Nanomaterials. 2019:9:18.
2. Salamanca-Buentello F, Persad DL, Court EB, Martin DK, Daar AS, Singer PA. Nanotechnology and the developing world. PLoS Med. 2005;2:e97.

3. Prabhu S, Poulose EK. Silver nanoparticles: mechanism of antimicrobial action, synthesis, medical applications, and toxicity effects. Int Nano Lett. 2012;2:1.

4. Dakal TC, Kumar A, Majumdar RS, Yadav V. Mechanistic basis of antimicrobial actions of silver nanoparticles. Front Microbiol. 2016;7:1831.

5. Zorraquín-Peña I, Cueva C, Bartolomé B, Moreno-Arribas MV. Silver nanoparticles against foodborne bacteria. Effects at intestinal level and health limitations. Microorganisms. 2020;8:132.

6. Lu Z, Rong K, Li J, Yang H, Chen R. Size-dependent antibacterial activities of silver nanoparticles against oral anaerobic pathogenic bacteria. J Mater Sci Mater Med. 2013;24:1465.

7. Ivask A, Kurvet I, Kasemets K, Blinova I, Aruoja V, Suppi S, et al. Sizedependent toxicity of silver nanoparticles to bacteria, yeast, algae, crustaceans and mammalian cells in vitro. PLoS ONE. 2014:9:1.

8. Khurana C, Vala AK, Andhariya N, Pandey OP, Chudasama B. Antibacterial activity of silver: the role of hydrodynamic particle size at nanoscale. J Biomed Mater Res Part A. 2014;102:3361.

9. Sadeghi B, Garmaroudi FS, Hashemi M, Nezhad HR, Nasrollahi A, Ardalan $\mathrm{S}$, et al. Comparison of the anti-bacterial activity on the nanosilver shapes: nanoparticles, nanorods and nanoplates. Adv Powder Technol. 2012;23:22.

10. Lu W, Yao K, Wang J, Yuan J. Ionic liquids-water interfacial preparation of triangular Ag nanoplates and their shape-dependent antibacterial activity. J Colloid Interface Sci. 2015;437:35.

11. Pal S, Tak YK, Song JM. Does the antibacterial activity of silver nanoparticles depend on the shape of the nanoparticle? A study of the gramnegative bacterium Escherichia coli. Appl Environ Microbiol. 2007:73:1712

12. Durán N, Durán M, de Jesus MB, Seabra AB, Fávaro WJ, Nakazato G. Silver nanoparticles: a new view on mechanistic aspects on antimicrobial activity. Nanomed Nanotechnol Biol Med. 2016;12:789.

13. Kim JS, Kuk E, Yu KN, Kim JH, Park SJ, Lee HJ, et al. Antimicrobial effects of silver nanoparticles. Nanomed Nanotechnol Biol Med. 2007;3:95.

14. Chen H, Wu J, Wu M, Jia H. Preparation and antibacterial activities of copper nanoparticles encapsulated by carbon. New Carbon Mater. 2019;34:382.

15. Lemire JA, Harrison JJ, Turner RJ. Antimicrobial activity of metals: mechanisms, molecular targets and applications. Nat Rev Microbiol. 2013;11:371.

16. Bogdanović U, Vodnik V, Mitrić M, Dimitrijević S, Škapin SD, Žunič V, et al. Nanomaterial with high antimicrobial efficacycopper/polyaniline nanocomposite. ACS Appl Mater Interfaces. 2015:7:1955.

17. Ashraf JM, Ansari MA, Khan HM, Alzohairy MA, Choi I. Green synthesis of silver nanoparticles and characterization of their inhibitory effects on AGEs formation using biophysical techniques. Sci Rep. 2016;6:1.

18. Kadiyala U, Kotov NA, VanEpps JS. Antibacterial metal oxide nanoparticles: challenges in interpreting the literature. Curr Pharm Des. 2018;24:896.

19. Farias IAP, Dos Santos CCL, Sampaio FC. Antimicrobial activity of cerium oxide nanoparticles on opportunistic microorganisms: a systematic review. Biomed Res Int. 2018;2018:1.

20. Appierot G, Lipovsky A, Dror R, Perkas N, Nitzan Y, Lubart R, et al. Enhanced antibacterial actiwity of nanocrystalline $\mathrm{ZnO}$ due to increased ROS-mediated cell injury. Adv Funct Mater. 2009;19:842.

21. Emami-Karvani Z, Chehrazi P. Antibacterial activity of ZnO nanoparticle on Gram-positive and Gram-negative bacteria. Afr J Microbiol Res. 2011;5:1368.

22. Tayel AA, El-Tras WF, Moussa S, El-Baz AF, Mahrous H, Salem MF, et al. Antibacterial action of zinc oxide nanoparticles against foodborne pathogens. J Food Saf. 2011;31:211.

23. Reddy KM, Feris K, Bell J, Wingett DG, Hanley C, Punnoose A. Selective toxicity of zinc oxide nanoparticles to prokaryotic and eukaryotic systems. Appl Phys Lett. 2007;90:1.

24. Pasquet J, Chevalier Y, Couval E, Bouvier D, Noizet G, Morlière C, et al. Antimicrobial activity of zinc oxide particles on five micro-organisms of the challenge tests related to their physicochemical properties. Int J Pharm. 2014;460:92.

25. Sánchez-López E, Gomes D, Esteruelas G, Bonilla L, Lopez-Machado AL, Galindo R, et al. Metal-based nanoparticles as antimicrobial agents: an overview. Nanomaterials. 2020;10:292. 
26. Dogsa I, Kriechbaum M, Stopar D, Laggner P. Structure of bacterial extracellular polymeric substances at different $\mathrm{pH}$ values as determined by SAXS. Biophys J. 2005;89:2711.

27. Shanmugam A, Kathiresan K, Nayak L. Preparation, characterization and antibacterial activity of chitosan and phosphorylated chitosan from cuttlebone of Sepia kobiensis (Hoyle, 1885). Biotechnol Rep. 2016;9:25

28. Armentano I, Arciola CR, Fortunati E, Ferrari D, Mattioli S, Amoroso CF, Kenny JM, Imbriani M, Visai L. The Interaction of bacteria with engineered nanostructured polymeric materials: a review. Sci World J. 2014;2014:410423

29. Banach M, Pulit J. Method of obtaining nanostructural zinc, iron, zironium,or copper oxides in the field of microwave radiation. Patent application. 2015

30. PN-EN 1040:2006.

31. PN-EN 1275:2006.

32. Parada J, Aguilera JM, Brennan C. Effect of guar gum content on some physical and nutritional properties of extruded products. J Food Eng. 2011;103:324

33. Gupta S, Variyar PS. Guar gum: a versatile polymer for the food industry. In: Biopolym Food Des. Amsterdam: Elsevier Inc.; 2018. p. 383.

34. El-Ashhab F, Sheha L, El-Dali A, Abdel Salam AE, Zubeir O. Viscous behavior of aqueous HEC in moderate concentration domain before after gamma irradiation. Arab J Nucl Sci Appl. 2005;38:35.

35. Wypych G. HEC hydroxyethyl cellulose. In: Handbook of polymers. 2012. p. 416-21.

36. Rochas C, Geissler E. Measurement of dynamic light scattering intensity in gels. Macromolecules. 2014;47:8012.

37. Sastry M, Mayya KS, Bandyopadhyay K. pH Dependent changes in the optical properties of carboxylic acid derivatized silver colloidal particles. Colloids Surfaces A Physicochem Eng Asp. 1997;127:221.

38. Mwafy EA, Abd-Elmgeed AA, Kandil AA, Elsabbagh IA, Elfass MM, Gaafar MS. High UV-shielding performance of zinc oxide/high-density polyethylene nanocomposites. Spectrosc Lett. 2015:48:646.

39. Dobrucka R, Długaszewska J. Biosynthesis and antibacterial activity of ZnO nanoparticles using Trifolium pratense flower extract. Saudi J Biol Sci. 2016:23:517.

40. Farhat FO, Alkadar M, Ganebr MY, Elgwel AM, Hisham M. Annealing effects on characterizations of $\mathrm{ZnO}$ thin films on flexible and nonflexible substrates. J Hum App Soc Sci. 2018;31:13.

41. Ching YC, Rahman A, Ching KY, Sukiman NL, Chuah CH. Preparation and characterization of polyvinyl alcohol-based composite reinforced with nanocellulose and nanosilica. BioResources. 2015:10:3364.

42. Nunes C, Mahendrasingam A, Suryanarayanan R. Quantification of crystallinity in substantially amorphous materials by synchrotron X-ray powder diffractometry. Pharm Res. 2005;22:1942.

43. Mukerabigwi JF, Lei S, Fan L, Wang H, Luo S, Ma X, et al. Eco-friendly nano-hybrid superabsorbent composite from hydroxyethyl cellulose and diatomite. RSC Adv. 2016;6:31607.

44. Mudgil D, Barak S, Khatkar BS. X-ray diffraction, IR spectroscopy and thermal characterization of partially hydrolyzed guar gum. Int J Biol Macromol. 2012:50:1035.

45. Das MP, Prasad K, Suguna PR, Vijaylakshmi JV. Extraction and characterization of gelatin: a functional biopolymer. Int J Pharm Pharm Sci. 2017;9:239

46. Kumar S, Koh J. Physiochemical, optical and biological activity of chitosan-chromone derivative for biomedical applications. Int J Mol Sci. 2012;13:6103.

47. Wahyuningsih K, Iriani ES, Fahma F. Utilization of cellulose from pineapple leaf fibers as nanofiller in polyvinyl alcohol-based film. Indones J Chem. 2016:16:181.

48. Hitkari G, Singh S, Pandey G. Structural, optical and photocatalytic study of $\mathrm{ZnO}$ and $\mathrm{ZnO}-\mathrm{ZnS}$ synthesized by chemical method. Nano-Struct Nano-Objects. 2017;12:1.

49. Kharazmi A, Faraji N, Hussin RM, Saion E, Yunus WMM, Behzad K. Structural, optical, opto-thermal and thermal properties of ZnS-PVA nanofluids synthesized through a radiolytic approach. Beilstein J Nanotechnol. 2015;6:529.
50. Wang Y, Zhou Q, Li B, Liu B, Wu G, Ibrahim M, Guanlin X, Hongye L, Guochang S. Differentiation in MALDI-TOF MS and FTIR spectra between two closely related species Acidovorax oryzae and Acidovorax citrulli. BMC Microbiol. 2012;12:182.

51. Lewis RN, McElhaney RN, Pohle W, Mantsch HH. Components of the carbonyl stretching band in the infrared spectra of hydrated 1,2-diacylglycerolipid bilayers: a reevaluation. Biophys J. 1994;67:2367.

52. Aracri E, Díaz Blanco C, Tzanov T. An enzymatic approach to develop a lignin-based adhesive for wool floor coverings. Green Chem. 2014;16:2597.

53. Khan MF, Ansari AH, Hameedullah M, Ahmad E, Husain FM, Zia Q, et al. Sol-gel synthesis of thorn-like $\mathrm{ZnO}$ nanoparticles endorsing mechanica stirring effect and their antimicrobial activities: potential role as nanoantibiotics. Sci Rep. 2016;6:1.

54. Kikuchi J, Komatsu T. Polysaccharides as major carbon sources in environmental biodiversity. New Dev NMR. 2017;10:369.

55. Salyers AA, McCarthy RE. Assessing the importance of host-derived polysaccharides as carbon sources for bacteria growing in the human colon. Anim Feed Sci Technol. 1989;23:109.

56. Slock JA, Stahly DP. Polysaccharide that may serve as a carbon and energy storage compound for sporulation in Bacillus cereus. J Bacteriol. 1974;120:399.

57. Chatterjee T, Chatterjee BK, Majumdar D, Chakrabarti P. Antibacterial effect of silver nanoparticles and the modeling of bacterial growth kinetics using a modified Gompertz model. Biochim Biophys Acta. 2015;1850:299.

58. Loo YY, Rukayadi Y, Nor-Khaizura MAR, Kuan CH, Chieng BW, Nishibuchi M, Radu S. In vitro antimicrobial activity of green synthesized silver nanoparticles against selected Gram-negative foodborne pathogens. Front Microbiol. 2018;9:1555.

59. Seong M, Lee DG. Silver nanoparticles against Salmonella enterica serotype typhimurium: role of inner membrane dysfunction. Curr Microbiol. 2017;74:661.

60. Abbaszadegan A, Ghahramani Y, Gholami A, Hemmateenejad B, Dorostkar S, Nabavizadeh M, Sharghi H. The effect of charge at the surface of silver nanoparticles on antimicrobial activity against gram-positive and gram-negative bacteria: a preliminary study. J Nanomater. 2015;16:53.

61. Panpaliya NP, Dahake PT, Kale YJ, Dadpe MV, Kendre SB, Siddiqi AG, et al In vitro evaluation of antimicrobial property of silver nanoparticles and chlorhexidine against five different oral pathogenic bacteria. Saudi Dent J. 2019;31:76

62. Petrus EM, Tinakumari S, Chai LC, Ubong A, Chai N, Son R. A study on the minimum inhibitory concentration and minimum bactericidal concentrationm of nano colloidal silver on food-borne pathogens. Int Food Res J. 2018;1:55.

63. Kędziora A, Gerasymchuk YS, Sroka EM, Bugla-Płoskońska G, Doroszkiewicz W, Rybak Z, et al. Use of the materials based on partially reduced graphene-oxide with silver nanoparticle as bacteriostatic and bactericidal agent. Polym Med. 2013;43:129.

64. Karimipour SN, Tanomand A. Evaluating the antibacterial activity of the nanoparticles of silver on Pseudomonas aeruginosa. Int J Med Res Health Sci. 2016;5:424.

65. Krishnan R, Arumugam V, Vasaviah SK. The MIC and MBC of silver nanoparticles against Enterococcus faecalis — a facultative anaerobe. $J$ Nanomed Nanotechnol. 2015;06:1.

66. Rautela A, Rani J, Debnath M. Green synthesis of silver nanoparticles from Tectona grandis seeds extract: characterization and mechanism of antimicrobial action on different microorganisms. J Anal Sci Technol. 2019;10:1.

67. Yousef MJ, Danial EN. In vitro antibacterial activity and minimum inhibitory concentration of zinc oxide and nano-particle zinc oxide against pathogenic strains. Int J Health Sci. 2012;2:38.

68. Nazoori ES, Kariminik A. Evaluation of antibacterial properties of $\mathrm{ZnO}$ nanoparticles. J Appl Biotechnol Rep. 2018;5:162.

69. Hadi N, Dawood H. Antibacterial activity of modified zinc oxide nanoparticles against Pseudomonas aeruginosa isolates of burn infections. World Sci News. 2016:33:1. 
70. Almoudi MM, Hussein AS, Abu Hassan MI, Mohamad ZN. A systematic review on antibacterial activity of zinc against Streptococcus mutans. Saudi Dent J. 2018;30:283.

71. Abdelhamid HN, Talibc A, Wu HF. Facile synthesis of water soluble silver ferrite $\left(\mathrm{AgFeO}_{2}\right.$ ) nanoparticles and their biological application as antibacterial agents. RSC Adv. 2015;5:34594.

72. Wu BS, Abdelhamid HN, Wu HF. Synthesis and antibacterial activities of graphene decorated with stannous dioxide. RSC Adv. 2014;4:3722.
73. Abdelhamid HN, Wu HF. Multifunctional graphene magnetic nanosheet decorated with chitosan for highly sensitive detection of pathogenic bacteria. J Mater Chem. 2013:1:3950.

\section{Publisher's Note}

Springer Nature remains neutral with regard to jurisdictional claims in published maps and institutional affiliations.
Ready to submit your research? Choose BMC and benefit from:

- fast, convenient online submission

- thorough peer review by experienced researchers in your field

- rapid publication on acceptance

- support for research data, including large and complex data types

- gold Open Access which fosters wider collaboration and increased citations

- maximum visibility for your research: over $100 \mathrm{M}$ website views per year

At BMC, research is always in progress.

Learn more biomedcentral.com/submissions 